\title{
DEVELOPMENT STRATEGY OF MINI-SCALE SHRIMP FARMING ON PLASTIC POND (BUSMETIK) IN GEMILANG MINAJAYA FISH FARMING GROUP OF TEGAL CITY
}

\author{
Sumiarsih, Hutabarat Johanes, Rejeki Sri \\ Coastal Resource Management Study Program, Department of Fisheries, \\ Faculty of Fisheries and Marine Sciences, University of Diponegoro, Indonesia \\ Phone: +62247474698
}

\begin{abstract}
Vannamei shrimp farming is a fisheries sub-sector that is being promoted by the government. The right strategy is needed in the development of vannamei shrimp farming, so that the farming activities can run sustainably. This research aimed to determine the management of vannamei shrimp farming activities, business analysis, internal and external factors and appropriate development strategies for Mini-Scale Shrimp Farming on Plastic Pond (BUSMETIK) in Tegal City. This research was descriptive research and did not test the hypothesis. This research used a case study method, which was a form of research aimed at describing existing phenomena. The sampling technique used was purposive sampling and the respondent collection technique used was non probability sampling. The data obtained were analyzed quantitatively and descriptively. In addition, business analysis and SWOT analysis were also conducted to the data. The sample chosen in this research was Gemilang Minajaya Fish Farming Group of Tegal City. The results showed that Gemilang Minajaya Fish Farming Group of Tegal City with a pond area of $1,221 \mathrm{~m}^{2}$ was a vannamei shrimp producing area that was quite influential in Tegal City, with production volume from 2018 reaching $2,111.21 \mathrm{Kg}$. However, its farming activities had not fully met Best Management Practice (BMP), especially in the process of managing farming waste and the lack of green belt areas. It was suspected that the high organic matter in water quality was caused by the results of the farming waste. The condition that currently attacked vannamei shrimp was a white feces disease. From business analysis point of view, the income was Rp. $46,469,122$ /cycle with business efficiency (R/C ratio) of 148 . Based on internal factor analysis, the greatest strength (S) was facilities and infrastructure (0.67) and external factor analysis showed that the biggest threat $(\mathrm{T})$ was shrimp disease ( 0.76$)$. The right alternative strategy was ST (Strengths-Threats) with a total score of 4.1 and the SWOT quadrant was in position II which was more likely to rely on existing strengths to take advantage of opportunities despite high threats. The alternative strategy used was to exploit the potential of existing land, optimize farm environmental factors to reduce threats of disease and establish cooperation with various fisheries stakeholders to establish green belt areas as an embodiment of sustainable and environmentally-friendly fisheries development.
\end{abstract}

\section{KEY WORDS}

Litopenaeus vannamei, business analysis, development strategy, white feces disease.

Vannamei shrimp (L.vannamei) is one of the leading commodities determined by the Ministry of Marine Affairs and Fisheries. This animal has a large market share which makes many investors want to invest their money in vannamei shrimp farming. The increasing demand for vannamei shrimp from year to year is based on the rapid growth of the world's population and awareness of fulfilling nutritional needs, where shrimp contains a lot of protein. Shrimps are the prima donna which have export potential, in which more than $50 \%$ of the country's foreign exchange from fishery products comes from shrimp commodities. Thus the shrimp industry is increasingly promising, especially with the introduction of vannamei shrimp species whose productivity reaches 6-10 tons/ha/year (Yasin, 2013).

The data above shows that the development of vannamei shrimp farming in Tegal City is very rapid. The potential can be developed for sure. The development of vannamei shrimp farming requires special studies so that the determined strategy can run well. In addition, 
determining the right strategy can also increase shrimp production as well as its sustainability. This research was conducted by approaching the technical aspects, economic aspects, as well as external and internal factors to develop a strategy for developing vannamei shrimp business. The technical aspects include the method of farming carried out by farmers, such as land preparation, stocking of seeds, feeding, harvesting, marketing and other farming activities related to technical aspects. The business analysis referred to in this research refers to the efficiency of vannamei shrimp farming. The concept of efficiency itself is the action of maximizing results by using minimal capital (labor, material and tools). Efficiency is the ratio between output and input (Mubyarto and Hamid, 1987). Internal and external factors are materials used for SWOT analysis. SWOT analysis is the identification of various factors systemically to formulate business development strategies. This analysis is based on logic that can maximize strengths and opportunities, but can simultaneously minimize weaknesses and threats (Rangkuti, 2001 ).

In order to develop vannamei shrimp farming, there are several obstacles to be solved, including costs. This is because the development of vannamei shrimp farming requires a large amount of capital which is also in line with the facilities needed to support farming activities. Besides, human resources (HR) are also needed in the technical field of vannamei shrimp farming because HR is one of the important factors in the success of vannamei shrimp farming. These factors are also supported by government policies and other supporting institutions. Therefore, a socio-economic study of the farming community in Tegal City is needed. With the harmony between various parties, it is expected that the production of vannamei shrimp farming can be increased and it can run sustainably.

The activity of developing vannamei shrimp farming has strengths and opportunities, but it is also faced with obstacles that can be either weakness or threat. These factors need to be identified as a consideration for the strategy of developing vannamei shrimp farming in Tegal City with a SWOT analysis approach. But beforehand, it would be better if the internal conditions of the vannamei shrimp farming business are known. Therefore, it is necessary to do a business analysis study.

The purpose of this research was to find out the profile and management of Mini-Scale Shrimp Farming on Plastic Pond in Tegal City, to know its business analysis, to analyze the conditions of internal factors (strengths and weaknesses) and external factors (opportunities and threats) of BUSMETIK in Tegal City, and to formulate development strategy of BUSMETIK in Tegal City. This research was conducted in June - August 2018, at Gemilang Minajaya Fish Farming Group. Secondary data collection was carried out in various related offices, such as the Marine and Fisheries Service of Tegal City.

\section{MATERIALS AND METHODS OF RESEARCH}

This research was descriptive research that aimed to describe systematically, factually and accurately about the facts and the nature of a particular population or region (Singarimbun, 1991). The research method used was a case study method, which was a form of research aimed at describing existing phenomena, both natural phenomena or human-engineered phenomena (Sukmadinata, 2007). The research sample was chosen intentionally (purposive), i.e the research location was chosen intentionally for certain reasons that were adjusted to the research objectives (Effendi, 1998) and the sampling technique used was non-probability sampling (Sugiyono, 2009). The sample chosen in this research was Gemilang Minajaya Fish Farming Group located in Tegal City. Gemilang Minajaya Fish Farming Group was chosen as the research sample because of its experience in vannamei shrimp farming and achievements.

This research did not test hypotheses or did not use hypotheses, but described existing information in accordance with the variables studied. Primary data was obtained from the results of surveys, interviews and questionnaires. Secondary data was obtained from literature studies (journals, books and internet) as well as data from related institutions. The research variables observed in this research included; profiles of vannamei shrimp farms; management of vannamei shrimp farming activities; variables for business analysis (fixed 
costs, variable costs, revenue, income, business efficiency); and variables for analyzing development strategies (SWOT analysis), namely strengths, weaknesses, opportunities and threats.

Stages of research conducted included; stage / which consisted of survey, observation, and interview to get information about BUSMETIK in Tegal City; stage II, namely secondary data collection sourced from the Marine and Fisheries Service (DKP) of Tegal City; stage III which consisted of questionnaire preparation for business analysis; stage IV was SWOT analysis based on identification of BUSMETIK problems in Tegal City; stage $V$ was SWOT questionnaire data collection and business analysis; stage VI was testing the validity and reliability of instrument data using Microsoft Office Excel 2007; and stage VII was data analysis.

Some data analyses used to review the Busmetik development strategies in Tegal City based on the data obtained were; (1) quantitive analysis, namely analysis of decisions using numbers; (2) descriptive analysis, namely the accumulation of basic data in a descriptive manner, which did not need to find or explain interconnectedness, to test hypotheses, to make predictions, or to get meaning or implications, although research aimed at finding these things can also include descriptive methods (Singarimbun, 1991); (3) business analysis which included; a. Cost; b. Revenue; c. Income; d. Business efficiency (R/C ratio) (Soekartawi, 2002); and (4) SWOT analysis, namely an analysis used to identify and evaluate internal and external factors, namely systematic identification of various factors to formulate development strategies (Rangkuti, 2006). This analysis is based on logic that can maximize strengths and opportunities, but simultaneously can minimize weaknesses and threats related to BUSMETIK development in Tegal City.

Table 1 - SWOT Matrix

\begin{tabular}{|c|c|c|}
\hline $\begin{array}{lr}\text { External } & \begin{array}{r}\text { Internal } \\
\text { Factor }\end{array} \\
\text { Factor }\end{array}$ & $\begin{array}{c}\text { STRENGTHS (S) } \\
\text { Determining 3-10 internal strength } \\
\text { factors }\end{array}$ & $\begin{array}{c}\text { WEAKNESSES }(\mathrm{W}) \\
\text { Determining 3-10 internal weakness } \\
\text { factors }\end{array}$ \\
\hline $\begin{array}{l}\text { OPPORTUNITIES }(\mathrm{O}) \\
\text { Determining 3-10 external } \\
\text { opportunity factors }\end{array}$ & $\begin{array}{l}\text { SO STRATEGY } \\
\text { Creating strategies to use strength } \\
\text { to take advantage of opportunities }\end{array}$ & $\begin{array}{c}\text { WO STRATEGY } \\
\text { Creating strategies that minimize } \\
\text { weaknesses to take advantage of } \\
\text { opportunities }\end{array}$ \\
\hline $\begin{array}{c}\text { THREATS }(\mathrm{T}) \\
\text { Determining } 3-10 \text { external } \\
\text { threat factors }\end{array}$ & $\begin{array}{c}\text { ST STRATEGY } \\
\text { Creating strategies to maximize } \\
\text { strength to overcome threats }\end{array}$ & $\begin{array}{c}\text { WT STRATEGY } \\
\text { Creating strategies that minimize } \\
\text { weaknesses to avoid threats }\end{array}$ \\
\hline
\end{tabular}

\section{RESULTS AND DISCUSSION}

Profile and Management of BUSMETIK Activities. Geographically, intensive vannamei shrimp farming carried out by Gemilang Minajaya Fish Farming Group is located in the coastal area of Panggung Urban Village, Tegal Timur Sub-District, Tegal City, Central Java Province, which was directly adjacent to the northern sea of Java and close to the Pantura main road (North Coast). Astronomically, farming sites are located at 6050'- 6053' South Latitude and 109008'- 109010' East Longtitude, the farming location is the surrounding land with coastal tourism areas. Ponds located in Gemilang Minajaya Fish Farming Group consist of 3 plots that are loaned by the Tegal City Government to be utilized by Gemilang Minajaya Fish Farming Group with an altitude of 3-4 meters above sea level and an average temperature of $26-32^{\circ} \mathrm{C}$.

Gemilang Minajaya Fish Farming Group is a fish farming group with vannamei shrimp commodities. The establishment of Gemilang Minajaya Fish Farming Group originated from members of Gulamah Joint Business Group (KUB) in dealing with famine, so that economic needs continued even though they did not carry out fishing activities. Famine is a problem that must be felt by every fisherman because fishing activities are very dependent on season and weather. From these problems, the members of the Gulamah Joint Business Group took the initiative to establish a group of cultivators/farmers so that the members' income would increase or remain in the low season. Several meetings between members of the Gulamah 
Joint Business Group which were assisted by Fisheries Extension Agency of Tegal City eventually formed a group of farmers who were named "Gemilang Minajaya" with a total of 13 people as its members. On July 6, 2017, Gemilang Minajaya Fish Farming Group was confirmed by the Panggung Urban Village Head with an Inauguration number $144 / 154 / \mathrm{VI} / 2017$ and on July 17, 2017, it was legally legalized by the number: AHU0010553.AH.01.07 Year 2017.

Water quality plays a vital role in BUSMETIK sustainability. This is because water acts as a medium for maintaining vannamei shrimp. The water quality in this research is divided into physical and chemical parameters.

Table 1 - Water Quality Parameters

\begin{tabular}{|c|c|c|c|c|c|}
\hline No & Parameter & Unit & Pond 1 & Pond 2 & $\begin{array}{c}\text { Standard } \\
\text { (SNI 01-7246-2006) }\end{array}$ \\
\hline 1. & pH & & 7.6 & 7.9 & $7.0-8.5$ \\
2. & Temperature & ${ }^{\circ} \mathrm{C}$ & 32 & 30 & $28-32$ \\
3. & DO & $\mathrm{ppm}$ & 4.2 & 3.6 & $>3$ \\
4. & Salinity & $\mathrm{ppt}$ & 25 & 25 & $>15$ \\
5. & TAN & $\mathrm{ppm}$ & 0.5 & 1 & $<2$ \\
6. & NH3 Union & $\mathrm{ppm}$ & 0.016 & 0.01 & $<0.01$ \\
7. & Alkalinity & $\mathrm{ppm}$ & 175 & 180 & $100-300$ \\
\hline- & Water Color & - & $\mathrm{HM}$ & - & - \\
\hline
\end{tabular}

Source : Water Quality Laboratory of Marine and Fisheries Service of Tegal City (2017).

Based on data from Water Quality Laboratory of Marine and Fisheries Service of Tegal City above, it can be seen that the water quality in BUSMETIK activities in Tegal City is in accordance with the water quality standards for vannamei shrimp farming. Thus, there are no problems with the available water quality.

The intensification of vannamei shrimp farming in Tegal City develops very tightly. The matter can be seen from the production volumes and values of vannamei shrimp. In 2016, the production volumes and values tended to experience an increase, the production volumes and values of vannamei shrimp can be seen in Table 2.

Table 2 - Production Value of Land Fisheries per Quarter according to the Type of Commodities in Tegal City in 2016 (000 Rupiah)

\begin{tabular}{lllcl}
\hline Period & Pond & Fish Pond & General Waters & Fish Seeds \\
\hline 1. Quarter I & 1653690 & 42240 & - & 32250.00 \\
2. Quarter II & 3102050 & 115040 & - & 14100.00 \\
3. Quarter III & 4393328 & 151632 & - & 8049.80 \\
4. Quarter IV & 3748610 & 214200 & - & 21000.00 \\
\hline Tegal City & 12897678 & 523112 & - & 75399.80 \\
\hline
\end{tabular}

Source: Marine, Fisheries, Agriculture and Food Service of Tegal City.

Based on interviews and observations, BUSMETIK management activities in Gemilang Minajaya Fish Farming Group of Tegal City include; (1) land preparation and repair, (2) biosecurity application, (3) water preparation, (4) prawns seeds selection and distribution, (5) feeding management, (6) water quality management, (7) harvesting and (8) waste management. Of the various BUSMETIK management activities in Tegal City, the main problem is the management of farming waste that has not been well accommodated. There is no WWTP in the farming area so that the wastewater is channeled directly to the water channel that empties into the sea and this will cause coastal pollution, while the water source used for farming comes from the coast.

Business Analysis. Business analysis study carried out in this research included: fixed costs /investment, variable costs/production, revenue, income, and business efficiency (R/C 
ratio) in BUSMETIK in Tegal City. The results of business analysis calculations can be seen in Table 3.

Table 3 - Results of Business Analysis of Mini-Scale Shrimp Farming on Plastic Pond in Gemilang Minajaya Fish Farming Group, Tegal City

\begin{tabular}{|c|c|c|c|c|c|}
\hline \multicolumn{7}{|c|}{ Average per Year* } \\
\hline Land Area (m2) & $\begin{array}{c}\text { Fixed Costs } \\
(\mathrm{Rp} .)\end{array}$ & $\begin{array}{c}\text { Variable Costs } \\
(\mathrm{Rp} .)\end{array}$ & $\begin{array}{c}\text { Revenue } \\
(\mathrm{Rp} .)\end{array}$ & $\begin{array}{c}\text { Income } \\
\text { (Rp.) }\end{array}$ & $\begin{array}{c}\text { Business Efficiency } \\
\text { (R/C ratio) }\end{array}$ \\
\hline 1221 & $18,583,500$ & $109,867,500$ & $156,336,622$ & $46,469,122$ & 1.48 \\
\hline
\end{tabular}

*Values apply at the time of Research Data Collection.

The problem that occurs in economic conditions in BUSMETIK activities in Gemilang Minajaya Fish Farming Group of Tegal City is the decline in production prices. This is due to the decline in shrimp prices in the market, so that $\mathrm{R} / \mathrm{C}$ ratio is 1.48 .

Analysis of Internal and External Factors for SWOT Analysis. Internal factor indicators have been established including: (1) production volume, (2) facilities and infrastructure, (3) land potential, (4) business partners, (5) farm environmental factors, (6) pond management activities, (7) human resources (HR), (8) funding, (9) production fluctuations, (10) farming products. The results of internal strategy factors/Internal Strategic Factor Analysis Summary (IFAS) are presented in Table 4.

Table 4 - Internal Strategy Factors Matrix

\begin{tabular}{|c|c|c|c|}
\hline Internal Strategy Factors & Weight & Rating & Score \\
\hline $\begin{array}{l}\text { STRENGTHS (S) } \\
\text {-Production Volume } \\
\text {-Facilities and Infrastructure } \\
\text {-Land Potential } \\
\text {-Business Partners } \\
\text {-Farm environmental factors }\end{array}$ & $\begin{array}{l}0.05 \\
0.14 \\
0.06 \\
0.13 \\
0.09\end{array}$ & $\begin{array}{l}1.80 \\
4.80 \\
2.20 \\
4.50 \\
3.10\end{array}$ & $\begin{array}{l}0.09 \\
0.67 \\
0.14 \\
0.59 \\
0.28\end{array}$ \\
\hline $\begin{array}{l}\text { WEAKNESSES (W) } \\
\text {-Pond Management Activities } \\
\text {-Human Resources (HR) } \\
\text {-Funding } \\
\text {-Production Fluctuations } \\
\text {-Farming Products }\end{array}$ & $\begin{array}{l}0.13 \\
0.09 \\
0.09 \\
0.09 \\
0.12\end{array}$ & $\begin{array}{l}4.40 \\
3.10 \\
3.20 \\
3.10 \\
4.10\end{array}$ & $\begin{array}{l}0.5 \\
0.28 \\
0.30 \\
0.28 \\
0.49\end{array}$ \\
\hline TOTAL & 0.99 & - & 3.62 \\
\hline
\end{tabular}

The number of weighting scores of internal variables (strengths and weaknesses) is equal to 3.62. According to Umar (2001), the position of Gemilang Minajaya Fish Farming Group is on favorable criteria. The position of Gemilang Minajaya Fish Farming Group in competition with a weighted score of 3.62 can be seen in Table 5.

Table 5 - Internal Variable Analysis

\begin{tabular}{|c|c|}
\hline Value & Competition Position \\
\hline $1.00-1.66$ & Need to be avoidec \\
$1.67-2.33$ & weak \\
$2.34-3.00$ & tenable \\
$3.01-3.67$ & favorable \\
$3.68-4.34$ & strong \\
$4.35-5.00$ & dominant \\
\hline
\end{tabular}

Source: Umar (2001).

External Analysis/External Strategic Factors Analysis Summary (EFAS), related to threats and opportunities that exist within Gemilang Minajaya Fish Farming Group environment. External variables are measured quantitatively to find out the opportunities and threats that exist. The results of the analysis of external factors are presented in Table 6. 
Table 6 - External Strategy Factors Matrix

\begin{tabular}{|c|c|c|c|}
\hline External Strategy Factors & Weight & Rating & Score \\
\hline $\begin{array}{l}\text { OPPORTUNIT⿰IES (O) } \\
\text {-Land Potential } \\
\text {-Demand on Shrimp Products } \\
\text {-Shrimp Economic Value } \\
\text {-Fishery Policy } \\
\text {-Pond Management Activities }\end{array}$ & $\begin{array}{l}0.07 \\
0.14 \\
0.12 \\
0.12 \\
0.07\end{array}$ & $\begin{array}{l}2.20 \\
4.60 \\
4.10 \\
4.00 \\
2.30\end{array}$ & $\begin{array}{l}0.15 \\
0.63 \\
0.50 \\
0.47 \\
0.16\end{array}$ \\
\hline $\begin{array}{ll} & \text { THREATS }(\mathrm{T}) \\
\text {-Product Competition } & \\
\text {-Shrimp Disease } & \\
\text {-Fishery Policy } & \\
\text {-Environmental Pollution } & \end{array}$ & $\begin{array}{l}0.12 \\
0.15 \\
0.08 \\
0.14\end{array}$ & $\begin{array}{l}4.10 \\
5.00 \\
2.70 \\
4.70\end{array}$ & $\begin{array}{l}0.51 \\
0.76 \\
0.22 \\
0.67\end{array}$ \\
\hline TOTAL & 1.01 & - & 4.07 \\
\hline
\end{tabular}

A favorable position means that the Gemilang Minajaya .Fish Farming Group is in。a safe condition in conducting farming activities. This is because other competitors are also in the same condition, namely in the condition of declining shrimp production due to white feces disease. The safe position must be addressed wisely, because the conditions can change at any time. Therefore, vannamei shrimp farmers in Tegal City must improve the farming system, especially pond management and shrimp production.

The analysis used to formulate a development strategy is SWOT matrix. The SWOT matrix is a combination of analysis of internal factors and external factors. The weight values of each SWOT element are presented in Table 7.

Table 7 - Weighting Value of Each SWOT Element

\begin{tabular}{|c|c|c|c|c|c|c|c|}
\hline Strengths & Value & Weakness & Value & Opportunities & Value & Threats & Value \\
\hline S1 & 0.09 & W1 & 0.56 & 01 & 0.14 & & \\
\hline S2 & 0.67 & W2 & 0.28 & $\mathrm{O} 2$ & 0.63 & T1 & 0.50 \\
\hline S3 & 0.14 & W3 & 0.30 & $\mathrm{O} 3$ & 0.50 & T2 & 0.74 \\
\hline S4 & 0.59 & W4 & 0.28 & $\mathrm{O} 4$ & 0.47 & T3 & 0.22 \\
\hline S5 & 0.28 & W5 & 0.49 & O5 & 0.16 & T4 & 0.66 \\
\hline Total & \multicolumn{2}{|c|}{1.99} & \multicolumn{2}{|r|}{1.35} & \multicolumn{2}{|c|}{1.90} & 2.11 \\
\hline
\end{tabular}

Alternative and Alternative Priorities for BUSMETIK Strategies. External factors/ External Strategic Factors Analysis Summary (EFAS) is related to threats and opportunities that exist within the environment of Gemilang Minajaya Fish Farming Group. External variables of score weighting in the SWOT table shows that the threat level on BUSMETIK is the highest (2.11). Although the level of competition is in a favorable position, farmers must be able to anticipate the threats that exist as early as possible, especially shrimp diseases. Existing threats can be minimized by utilizing the existing strengths and opportunities. This is done so that BUSMETIK development is successful. To realize this goal, the right strategy is needed in developing BUSMETIK in Gemilang Minajaya Fish Farming Group of Tegal City.

The results of the calculation of the analysis of internal factors and external factors above are then combined into the SWOT matrix which aims to formulate and determine the alternative strategies for developing BUSMETIK in Gemilang Minajaya Fish Farming Group of Tegal City. Alternative strategies are presented in Table 8.

Alternative strategy priorities in the research on BUSMETIK development prospects in Gemilang Minajaya Fish Farming Group in Tegal City can be seen by adding scores from SO, ST, WO and WT. Based on the weighting carried out, the priority of the strategy based on the SWOT ranking can be seen. Alternative strategies ranking for BUSMETIK development in Gemilang Minajaya Fish Farming Group of Tegal City can be seen in Table 10.

Figure 1 shows BUSMETIK development strategies in Gemilang Minajaya Fish Farming Group in the competitive (quadrant) position. This indicates that BUSMETIK activities at Gemilang Minajaya Fish Farming Group of Tegal City face various threats, but still have internal strength. The strategy implemented is to use strengths to take advantage of 
the opportunities that exist in carrying out intensive vannamei shrimp farming.

Table 8 - Formulation of Alternative Strategies for BUSMETIK Development in Gemilang Minajaya Fish Farming Group of Tegal City

\begin{tabular}{|c|c|c|}
\hline$X$ & $\begin{array}{l}\text { Strengths (S) } \\
\text { - Production Volume } \\
\text { - Facilities and Infrastructure } \\
\text { - Land Potential } \\
\text { - Business Partners } \\
\text { - Farm environmental factors }\end{array}$ & $\begin{array}{l}\text { Weaknesses (W) } \\
\text { - Pond Management Activities } \\
\text { - Human Resource (HR) } \\
\text { - Funding } \\
\text { - Production Fluctuation } \\
\text { - Farming Products }\end{array}$ \\
\hline $\begin{array}{l}\quad \text { Opportunities (O) } \\
\text { - Land Potential } \\
\text { - Demand on Shrimp } \\
\text { Products } \\
\text { - Shrimp Economic } \\
\text { Value } \\
\text { - Fishery Policy } \\
\text { - Pond Management } \\
\text { Activity }\end{array}$ & $\begin{array}{l}\text { S-O STRATEGY } \\
\text { 1. Increasing the volume of vannamei } \\
\text { shrimp production to meet the growing } \\
\text { demand for shrimp products. } \\
\text { 2. Adding other business partners related } \\
\text { to farming activities and other sectors such } \\
\text { as investors and stakeholders. } \\
\text { 3. Improving pond management activities } \\
\text { by taking into account farm environmental } \\
\text { factors, the concept of biosecurity, Best } \\
\text { Management Practices (BMP) and utilizing } \\
\text { existing facilities and infrastructure. }\end{array}$ & $\begin{array}{l}\text { W-O STRATEGY } \\
\text { 1.Improving the competence and } \\
\text { professionalism of human resources } \\
\text { (HR). } \\
\text { 2.Improving the quality of cultivated } \\
\text { vannamei shrimp to meet shrimp } \\
\text { demand in the local and export } \\
\text { markets, where good quality shrimp will } \\
\text { also have high economic value in the } \\
\text { market. This strategy also aims to } \\
\text { overcome funding problems. } \\
\text { 3.Utilizing government policies that } \\
\text { support fisheries development } \\
\text { especially for the cultivation sector. }\end{array}$ \\
\hline $\begin{array}{l}\text { Threats }(\mathrm{T}) \\
\text { - Product Competition } \\
\text { - Shrimp Disease } \\
\text { - Fishery Policy } \\
\text { - Environmental Pollution }\end{array}$ & $\begin{array}{l}\text { S-T STRATEGY } \\
\text { 1. Utilizing the potential of land and existing } \\
\text { facilities and infrastructure to suppress } \\
\text { product competition. } \\
\text { 2. Optimizing farm environmental factors to } \\
\text { reduce the threat of shrimp disease. } \\
\text { 3. Organizing cooperation with business } \\
\text { partners and also the government to hold } \\
\text { green belt areas as an embodiment of the } \\
\text { development of environmentally-friendly } \\
\text { and sustainable vannamei shrimp } \\
\text { cultivation and minimizing environmental } \\
\text { pollution. }\end{array}$ & $\begin{array}{l}\text { W-T STRATEGY } \\
\text { 1. Improving pond management } \\
\text { activities, especially the problem of } \\
\text { waste management. } \\
\text { 2. Preparing competent human } \\
\text { resources (HR) in national and global } \\
\text { competition and being ready to } \\
\text { compete with other regions. } \\
\text { 3. Applying appropriate fisheries } \\
\text { policies on the results of farming } \\
\text { products, so as to stimulate farmers to } \\
\text { produce high quality shrimp products. }\end{array}$ \\
\hline
\end{tabular}

Table 9 - Alternative Strategies Ranking for BUSMETIK Development in Gemilang Minajaya Fish Farming Group of Tegal City

\begin{tabular}{lllll}
\hline No. & Alternative Strategies & Value & Total Score & Rank \\
\hline 1. & ST (Strengths-Threats) & $1.99+2.11$ & 4.1 & 1 \\
2. & SO (Strentghs-Opportunities) & $1.99+1.90$ & 3.89 & 2 \\
3. & WT (Weakness-Threats) & $1.35+2.11$ & 3.46 & 3 \\
4. & WO (Weakness-Opportunities) & $1.35+1.90$ & 3.25 & 4 \\
\hline
\end{tabular}

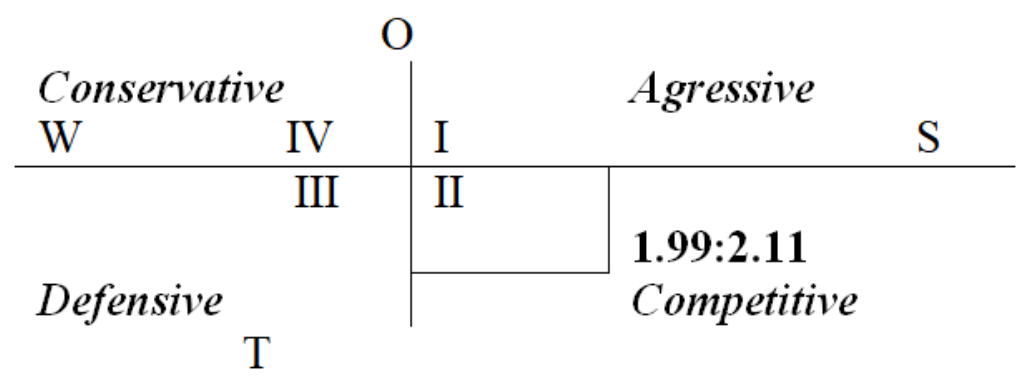

Figure 1 - Quadrant of BUSMETIK development strategies in Gemilang Minajaya Fish Farming Group of Tegal City 


\section{DISCUSSION OF RESULTS}

Profile and Management of BUSMETIK Activities in Gemilang Minajaya Fish Farming Group of Tegal City. Based on Table 2, Tegal City has a productive farming pond area, it can be seen from the production in 2016 which experiences an increase quarterly. This shows that pond farming in Tegal City can be developed well, especially the vannamei shrimp commodity with BUSMETIK technology. If it is developed further, it can increase production.

Based on Table 1 (Water Quality Parameters) above it can be seen that the main problem of water quality in intensive vannamei shrimp farming activities in Tegal City is the high content of organic materials such as ammonia, nitrite, nitrate and phosphate. The high organic matter in the pond waters was allegedly caused by feed that did not decompose properly, as well as the lack of management of pond water quality so that the bottom of the pond waters has the potential to have high organic matter content. This is reinforced by Boyd (1990), that organic material comes from non-inedible feed, dead plankton, and the application of shrimp fertilization and feces on an ongoing basis which accumulates at the bottom of the pond. Pantjara and Rachmansyah (2010) stated that the application of probiotics by adding molasses in water can improve water quality which leads to increased growth and survival of vannamei shrimp.

Business Analysis Study. From the business analysis data (Table 3), it is shown that the level of net income and business efficiency of BUSMETIK at Gemilang Minajaya Fish Farming Group is currently optimal. Net income per cycle of Rp.46,469,122 with an area of $1,221 \mathrm{~m}^{2}$ should be able to be increased. In addition, the efficiency level is almost close to 1 . This means that the revenue obtained by farmers is almost close to the total costs incurred. Farmers mentioned that the problem of decreasing production was caused by the spread of White Feces Disease in vannamei shrimp which caused the growth of shrimp to slow down and there were several deaths. This certainly affects the level of Food Convertion Ratio (FCR), where feed in farming ranks first in production costs. The high feed expenditure is not balanced by the biomass of cultivated vannamei shrimp production. Under these conditions, farmers are encouraged to adjust stocking densities as well as the feed program provided. Feed is one of the important aspects in every aquatic farming activity. Feed is the largest production factor and reaches $50 \%$ or more of the total operational costs, so it needs to be managed properly so that it can be used efficiently for the cultivation. A good feeding program is needed to obtain maximum results in shrimp and fish farming activities (Nur, 2011). The reduced production volume until mid-2016 was coupled with the decline in the price of vannamei shrimp in the market. From the data obtained from the field (in August 2018), shrimp prices were determined based on size, namely: size $120=R p .32,000 / \mathrm{Kg}$; size $100=\mathrm{Rp} .45,000 / \mathrm{Kg}$; size $60=\mathrm{Rp} .62,000 / \mathrm{Kg}$; and size $50=\mathrm{Rp} .72,000 / \mathrm{Kg}$. The price was considered by farmers to be less in line with the operational costs incurred. The causes of the decline in prices have not been known with certainty by the farmers. However, according to information obtained, the cause of the decline in shrimp prices was alleged by competition with other countries shrimp products and also the quality of shrimp due to white feces disease which causes porous shrimp texture. In addition, Indonesia's current economic conditions also have a direct impact on rising production costs for vannamei shrimp, such as rising diesel prices and other production facilities.

Analysis of External and Internal Factors in SWOT and Alternative Strategies and Priorities in BUSMETIK Development in Gemilang Minajaya Fish Farming Group of Tegal City. Based on the results of the internal strategy factor matrix analysis (Table 4), the greatest strengths (S) in BUSMETIK in Tegal Gemilang Minajaya Fish Farming Group are facilities and infrastructure (0.67) and business partners (0.59). This strength must be added by optimizing existing facilities and infrastructure and adding business partners in fields other than food and seeds. The biggest weakness in the development of BUSMETIK in Gemilang Minajaya Fish Farming Group of Tegal City is pond management activities (0.5) and farming products (0.49). These two factors are the most logical reasons why shrimp production has decreased, especially the management of waste and farming products that have not met the standards. Tegal City (Table 5) is categorized in the criteria of favorable. A favorable position 
means that Tegal City is in a safe condition in conducting farming activities. This is because other competitors are also in the same condition, namely in the condition of declining shrimp production due to white feces disease. Based on the external factor strategy matrix (Table 6), the biggest opportunity for BUSMETIK development is the demand for shrimp products (0.63). According to the literature study conducted, the biggest demand comes from America, where Indonesia becomes the largest supplier of shrimp in the country. Meeting the needs of the shrimp market must also be accompanied by the quality of the shrimp itself, where shrimp must be free from disease (industri.bisnis.com). The biggest threats found in the development of BUSMETIK in Gemilang Minajaya Fish Farming Group of Tegal City are shrimp disease (0.76) and environmental pollution (0.67). These two things are the main problems in intensive vannamei shrimp farming. Waste of organic matter that is not handled properly can be a cause of shrimp disease. The consequence of this is the decrease in the quantity and quality of production.

Weighting value in the SWOT table (Table 7) shows that the threat level in vannamei shrimp farming is the highest (2.11). Existing threats can be minimized by utilizing existing strengths and opportunities. The SWOT matrix is a tool used to compile corporate strategic factors (Rangkuti, 2001). This matrix can clearly illustrate how external opportunities and threats are faced in BUSMETIK development activities at Gemilang Minajaya Fish Farming Group of Tegal City. The strategies produced are ST (Strengths-Threats) strategy, SO (Strength-Opportunities) strategy, WT (Weakness-Threats) strategy and WO (WeaknessOpportunities) strategy.

The ST strategy creates a strategy that utilizes strength (S) to overcome threats $(T)$. Figure 1 shows the Busmetik development strategies in Gemilang Minajaya Fish Farming Group of Tegal City in the competitive (quadrant) position. This indicates that BUSMETIK activities in Tegal City face various threats, but still have internal strength. The first rank is the ST strategy with a weight of 4.1 (Table 9). Alternative strategies (Table 8) that can be done in accordance with priorities include: (1) utilizing the potential of land and existing facilities and infrastructure to suppress product competition. Land use must also pay attention to carrying capacity to minimize the possibility of environmental pollution and its impacts such as shrimp disease, cultural competition, and also for efficiency and exclusion; (2) optimizing farm environmental factors to reduce the threat of shrimp disease. This is also supported by improved management of pond activities that consider CBIB or Best Management Practices (BMP) of vannamei shrimp farming; (3) cooperating with business partners and the government to hold green belt areas as an embodiment of the development of environmentally-friendly and sustainable vannamei shrimp farming and minimizing water pollution.

The ST strategy is a strategy that relies on internal strengths to deal with existing threats. It is expected that with this strategy, farmers can anticipate existing conditions with their strengths and improve the management of vannamei shrimp farming (Marimin, 2004).

\section{CONCLUSION AND RECOMMENDATIONS}

The conclusions that can be drawn from the research on Development Strategy of Mini-Scale Shrimp Farming On Plastic Pond (Busmetik) In Gemilang Minajaya Fish Farming Group of Tegal City are as follows:

BUSMETIK activities in Gemilang Minajaya Fish Farming Group of Tegal City have a major contribution to Tegal City with production from 2018 reaching $2,111.21 \mathrm{Kg}$ with a production value of Rp. 156,336,662, - The main problem at this time is the spread of white feces disease which is allegedly caused by a decrease in the quality of the farming environment. BUSMETIK activities at Gemilang Minajaya Fish Farming Group of Tegal City have also not adhered to sustainable and environmentally sound farming development, this can be seen from the management of waste management and the lack of green belt areas in Tegal City.

Revenues in 1 cycle in 2018 in BUSMETIK activities at Gemilang Minajaya Fish Farming Group of Tegal City is Rp.46,469,122, - with business efficiency of 1.48. However, 
this number can be increased by suppressing white feces disease which causes a decrease in production. In addition, the low value of business efficiency is caused by the decline in vannamei shrimp prices and and increase in operational costs.

Based on the calculation of the internal strategy factor matrix (IFAS), the greatest strength (S) is facilities and infrastructure (0.67) and the biggest weakness (W) is pond management activities (0.56). Based on the calculation of the external strategy matrix (EFAS), the biggest opportunity (O) is the demand on shrimp products $(0.63)$ and the biggest threat $(T)$ is shrimp disease (0.74); and based on the SWOT analysis, the alternative strategy rankings obtained are ST strategy (Strengths - Threats) (total score of 4.1), SO strategy (Strengths - Opportunities) (total score of 3.89), WT strategy (Weakness - Threats) (total score of 3.46), and WO strategy (Weakness - Opportunities) (total score of 3.25).

Based on the SWOT analysis, the alternative strategy rankings obtained are ST strategy (Strengths - Threats) (total score of 4.1), SO strategy (Strengths - Opportunities) (total score of 3.89), WT strategy (Weakness - Threats) (total score of 3.46), and WO strategy (Weakness - Opportunities) (total score of 3.25); The alternative strategic priorities used are utilizing the potential of existing land, optimizing farm environment factors to reduce the threats of disease and collaborating with various fisheries stakeholders to establish green belt areas as an embodiment of sustainable and environmentally-friendly fisheries development.

Suggestions that can be given from the research conducted is that further studies are needed, namely: studies on policies that are in accordance with the conditions and situations of current vannamei shrimp farming; studies of the development model of environmentally sound farming areas; and studies of the problems of shrimp prices and the factors that influence them.

\section{REFERENCES}

1. Boyd,C.E.1990. Water Quality in Ponds for Aquaculture. Alabama Agricultural Expe riment Station .Auburn University. Birmingham Publishing. USA. Diana, J.S. 2009. Aquaculture Production and Biodiversity Conservation. Bio Science.Vol. 59 No.1.

2. Effendi,I.1998.Faktor-Faktor Eksterna lyang Mengancam Kelestarian Produktivitas Tambak. [Makalah] Bogor. PKSPL-IPB.

3. Hogarth,P.J.1999.TheBiologyofMangrove.OxfordUniversityPressInc.NewYork.

4. Hudaidah,S.,Kahfi,A.,Akbaidar,G.A.,Wardiyanto,Adiputra,Y.T.2014. Modifikasi Biosekuritas, Peningkatan Performa Tambak dan Keberlanjutan Budidaya Udang Vannamei (Litopenaeus vannamei) diKabupaten Pesawaran Provinsi Lampung .Jurnal Ilmu Perikanan dan Sumberdaya Perairan.Aquasains:169-176.

5. Industri.bisnis.com.2014. Harga Udang: Jatuh diPasar Internasional. Produksi Meningkat. Diakses pada tanggal 20 Juli 2015.

6. Kathiresan,K. Dan B.L. Bingham. 2001. Biology of Mangrove and Mangrove Ecosystem .Centre of Advance Studyin Marine Biology. Annamalai University. Huxely College of Enviromental Studies. Western Washington University. Annamalai. India.

7. Limsuwan,C.2010. White Feces Diseasein Thailand. Boletines Nicotiva.

8. www.nicovita.com.pe.di akses tangga I2 Juli 2015.

9. Marimin.2004.Pengantar Keputusan Kriteria Majemuk. PT Gramedia Pustaka. Jakarta.

10. Mubyarto dan Suandi Hamid(ed.).1987. Meningkatkan Efisiemsi Nasional. BPFE.UGM. Yogyakarta.

11. Nur,A.2011. Manajemen Pemeliharaan Udang Vannamei. Badan Pengembangan SDM Kelautan dan Perikanan. Kementerian Kelautan dan Perikanan. HIm.8. BPSDM Kelautan dan Perikanan.KKP.

12. Pantjara B. Dan Rachmansyah. 2010. Efisiensi Pakan Melalui Penambahan Molasep ada Budidaya Udang vannamei Salinitas Rendah. Prosiding Forum Inovas i Teknologi Akuakultur. Balai Riset Perikanan Budidaya Air Payau. SulawesiSelatan.

13. Pramudji.2004.Mangrove di Pesisir Delta Mahakam Kalimantan Timur. Pusat Penelitian Oceanografi .LIPI .Jakarta. 
14. Rangkuti,F.2001. Analisis SWOT Teknik Membedah Kasus Bisnis PT.GramediaPustakaUtama.Jakarta.

15. Rangkuti,F.2006.Teknik Membedah Kasus Bisnis: Analisa SWOT Cetakan keempatbelas. Gramedia Pustaka.J akarta.Singarimbun, M.1991. Metode Penelitian Survei .LP3ES. Jakarta.

16. Soekarwati.2002.Teori Ekonomi Produksi. Rajawali Pers. Jakarta.

17. Sugiyono. 2009. Metode Penelitian Kuantitatif, Kualitatif dan R\&D cetakan ke8. Alfabeta. Bandung.

18. Sukmadinata, N.S.2007. Pengembangan Kurikulum Teoridan Praktek. PT.Remaja Rosdakarya. Bandung.

19. Umar, H.2001. Strategic Managementin Action. Gramedia Pustaka. Jakarta.

20. Yasin,M.2013.Analisa Ekonomi Usaha Tambak Udang Berdasarkan Luas Lahan Di KabupatenParigi Moutong Provinsi Sulawesi Tengah.No.2 Edisi September 2013. Jurnal IImiah Agr IBA. 